\title{
Type C oncornavirus isolation studies in systemic lupus erythematosus
}

\section{Attempted detection by isopycnic sedimentation of ${ }^{3} \mathrm{H}$-uridine-labelled virions}

\author{
PAUL E. PHILlips, RITA HARGRAVE, ELAINE STEWART, AND \\ NURUL H. SARKAR
}

From the Departments of Medicine, Hospital for Special Surgery, Memorial-Sloan-Kettering Cancer Center, and Cornell University Medical College, New York

\begin{abstract}
Phillips, P. E., Hargrave, R., Stewart, E., and Sarkar, N. H. (1976). Annals of the Rheumatic Diseases, 35, 422-428. Type C oncornavirus isolation studies in systemic lupus erythematosus. I. Attempted detection by isopycnic sedimentation of ${ }^{3} \mathbf{H}$-uridinelabelled virions. Type $\mathrm{C}$ oncornavirus isolation was attempted from cell cultures of tissues from 7 patients with systemic lupus erythematosus. Detection was based on the characteristic sedimentation of ${ }^{3} \mathrm{H}$-uridine-labelled virions at a density of $1 \cdot 16 \mathrm{~g} / \mathrm{ml}$. Cultures positive by this method were negative by two other criteria for type $\mathrm{C}$ viruses: characteristic virions by electron microscopy and the viral enzyme RNA-directed DNA polymerase. The positive results were probably due to cellular damage by prolonged radiolabelling, with release of organelles containing labelled RNA sedimenting at the same density as type $\mathrm{C}$ viruses.
\end{abstract}

The hypothesis that a virus is involved in the pathogenesis of systemic lupus erythematosus (SLE) is widely accepted although most attempts at implicating specific viruses have been negative (Ziff, 1971; Christian and Phillips, 1973; Phillips, 1975a). The similarity of SLE and New Zealand mouse disease, where type $\mathrm{C}$ oncornaviruses are definitely involved (Yoshiki and others, 1974; Levy and others, 1975), suggest that this class of viruses is the most likely aetiological candidate in SLE (Phillips, 1975a). Recent studies suggest that the expression of type $C$ virus-related antigens may be enhanced in SLE (Lewis and others, 1974; Strand and August, 1974), but no isolation attempts have been reported.

In this study isolation of type $\mathrm{C}$ viruses was attempted from cell cultures of tissues from SLE patients, using methods previously successful in isolating such viruses from other species (Todaro, 1974). Detection was based on a physical characteristic of type $C$ virions: their isopycnic sedimentation in sucrose gradients at a density of $1 \cdot 15-1 \cdot 17 \mathrm{~g} / \mathrm{ml}$.
This can be readily detected by intrinsically radiolabelling the virus RNA with ${ }^{3} \mathrm{H}$-uridine (Robinson, Pitkanen, and Rubin, 1965).

\section{Materials and methods}

\section{PATIENTS}

Ten separate experiments were done on specimens obtained from 8 patients (Table I); Case 1 was studied twice and the culture from Case 5 was studied twice. 7 patients had SLE according to the American Rheumatism Association criteria (Cohen and others, 1971), one of whom (Case 6) also had features of rheumatoid arthritis; one patient (Case 8) had chronic discoid LE. Various types of specimens (Table I) were obtained during the course of routine diagnostic and/or therapeutic procedures, the need for which was determined independently of the investigators.

\section{CELl CULTURES}

SLE organ tissues were obtained aseptically in medium 199 with $20 \%$ fetal calf serum and antibiotics, minced, washed with Hanks's balanced salt solution, and dissociated with $0.25 \%$ trypsin using standard methods 
Table I Patients, specimens, and cell cultures

\begin{tabular}{|c|c|c|c|c|c|}
\hline \multicolumn{4}{|c|}{ Patient } & \multicolumn{2}{|c|}{ Culture before testing } \\
\hline $\begin{array}{l}\text { Case } \\
\text { no. }\end{array}$ & Diagnosis* & Specimen $\dagger$ & Method & $\begin{array}{l}\text { Duration } \\
(m)\end{array}$ & $\begin{array}{l}\text { No. of } \\
\text { subcultures }\end{array}$ \\
\hline $1 \mathrm{~A}$ & SLE & PBL & Venepuncture & $\mathbf{0}$ & - \\
\hline $1 \mathrm{~B}$ & c"̄: & PBL & Venepuncture & 0 & $\overline{1}$ \\
\hline 2 & SLE & Spleen & Surgical & 4 & 1 \\
\hline 3 & SLE & Synovium & Surgical & 6 & 3 \\
\hline 4 & SLE & Kidney & Surgical & 18 & 10 \\
\hline $5 \mathrm{~A}$ & SLE & PC & Abortion & $<1$ & $\mathbf{0}$ \\
\hline 5B & "ב & "” & $"$ & 3 & 3 \\
\hline 6 & SLE/RA & Spleen & Surgical & $\mathbf{0}$ & - \\
\hline 7 & SLE & Placenta & Caesarean section & $\mathbf{0}$ & - \\
\hline 8 & DLE & Placenta & Term delivery & $\mathbf{0}$ & - \\
\hline
\end{tabular}

* SLE, systemic lupus erythematosus; SLE/RA, SLE with features of rheumatoid arthritis; DLE, discoid LE.

$\dagger$ PBL, peripheral blood leucocytes; PC, 2 month products of conception.

(Phillips, 1971; Kruse and Patterson, 1973). In five experiments the SLE cells were subsequently grown in medium 199 with $20 \%$ fetal calf serum in Falcon plastic flasks (Bioquest, Oxnard, Calif.) as monolayer fibroblast cultures for periods of one week to 18 months, with periodic subcultures using trypsin, before testing for type $C$ viruses (Table $\mathrm{I}$ ). In the other five experiments, the cell suspensions were tested immediately (Table $I$ ). Peripheral blood leucocytes (PBL) were obtained by gravity sedimentation at $37^{\circ} \mathrm{C}$ of heparinized blood after addition of an equal volume of fetal calf serum. The leucocyte-containing plasma was collected and diluted $1: 5$ in minimum essential medium (MEM) before use (Kruse and Patterson, 1973).

For cocultivation, four kinds of non-SLE cells were used (Table II) as potentially permissive cells for virus replication: a human synovial fibroblast line from a patient with degenerative hip disease (initiated 7 months earlier and used after its 5th subculture), fresh normal human PBL, and two continuous animal cell lines (Benveniste, Lieber, and Todaro, 1974b; Henderson, Lieber, and Todaro, 1974), derived from rabbit cornea (SIRC, CCL 60) and mink lung (Mv $1 \mathrm{Lu}, \mathrm{CCL}$ 64; American Type Culture Collection, Rockville, Md.). These cell lines were maintained like the SLE cells, except that $10 \%$ fetal calf serum was used for the animal lines. Sera were heated $\left(56^{\circ} \mathrm{C}, 30 \mathrm{~min}\right)$ before use. All cultures were incubated at $37^{\circ} \mathrm{C}$ in a humidified atmosphere of air and $5 \% \mathrm{CO}_{2}$. Viable cell counts were determined by trypan blue dye exclusion (Kruse and Patterson, 1973). All culture reagents were obtained from Microbiological Associates (Bethesda, Md.) except as specified.

\section{COCULTIVATION}

The trypsinized suspensions of SLE cells were mixed with each of the non-SLE cells used (Table II) in $5 \mathrm{ml}$ MEM with $10 \%$ fetal calf serum in plastic multidishes (Linbro Chemical Co., New Haven, Conn.). Experiments using PBL and fresh spleen cells (1A, 1B, 6) were done in 3 and $6 \mathrm{ml}$ replicates of the same medium in plastic screwcap tubes (Falcon) incubated upright. Final concentrations of SLE cells ranged from $2 \times 10^{4}$ to $2 \times 10^{6} / \mathrm{ml}$ medium, and the ratio of SLE to non-SLE cells from 1:1 to 200:1. In all experiments, SLE cells alone and, as controls, the non-SLE cells alone were also tested. Cultures were subsequently fed fresh MEM with $10 \%$ fetal calf serum twice a week. The experiments were maintained for periods of up to 14 weeks (Table II). Subcultures (Table II) were done using trypsin.

Table II SLE cell culture test conditions for type C virus isolation attempts

\begin{tabular}{|c|c|c|c|c|c|}
\hline $\begin{array}{l}\text { Experiment } \\
\text { no. }\end{array}$ & $\begin{array}{l}\text { Non-SLE cells used } \\
\text { for cocultivation* }\end{array}$ & Virus inducers $\dagger$ & $\begin{array}{l}\text { Duration of } \\
\text { test }(w)\end{array}$ & $\begin{array}{l}\text { No. of } \\
\text { subcultures }\end{array}$ & $\begin{array}{l}\text { No. of } \\
\text { radiolabellings }\end{array}$ \\
\hline $\begin{array}{l}1 \mathrm{~A} \\
1 \mathrm{~B} \\
2 \\
3 \\
4 \\
5 \mathrm{~A} \\
5 \mathrm{~B} \\
6 \\
7 \\
7 \mathrm{~T}_{+}^{+} \\
8\end{array}$ & $\begin{array}{l}\text { Normal human PBL } \\
\text { Rabbit } \\
\text { Human degener- } \\
\text { ative joint } \\
\text { disease synovial } \\
\text { fibroblasts } \\
\text { Rabbit and mink } \\
\text { Rabbit } \\
\text { Rabbit and mink } \\
\text { Rabbit and mink } \\
\text { Rabbit }\end{array}$ & $\begin{array}{l}\text { PHA, IDU } \\
\text { IDU (3) } \\
\text { IDU } \\
\text { IDU } \\
\text { IDU } \\
\text { IDU } \\
\text { IDU (2) } \\
\text { IDU } \\
\text { IDU, DXM } \\
\text { DEAE, DXM (c) } \\
\text { IDU (2) }\end{array}$ & $\begin{array}{r}2 \\
6 \\
3 \\
3 \\
3 \\
3 \\
14 \\
2 \\
8 \\
7 \\
3\end{array}$ & $\begin{array}{l}0 \\
0 \\
0 \\
0 \\
0 \\
0 \\
2 \\
1 \\
2 \\
3 \\
1\end{array}$ & $\begin{array}{l}2 \\
7 \\
1 \\
1 \\
1 \\
1 \\
6 \\
1 \\
7 \\
9 \\
2\end{array}$ \\
\hline
\end{tabular}

* See text for details.

† PHA, phytohaemagglutinin; IDU, 5-iododeoxyuridine; DEAE, DEAE-dextran; DXM, dexamethasone; ( ), number of times used; (c), used continuously.

† Transmission experiment from no. 7 . 
Attempted transmission of possible viral peaks was done by inoculation onto mink and rabbit cell monolayers in multidishes. To aid virus attachment (Toyoshima and Vogt, 1969), cells were pretreated with $25 \mu \mathrm{g}$ DEAEdextran (molecular weight $2 \times 10^{6}$; Pharmacia, Piscataway, N.J.) per ml Hanks's balanced salt solution for 1 hour at $37^{\circ} \mathrm{C}$. They were then washed once and $0.5 \mathrm{ml}$ of the test materials inoculated. After incubation for $\mathbf{3 0}$ minutes at $37^{\circ} \mathrm{C}$, the cultures were fed with medium containing $0.001 \mathrm{mmol} / \mathrm{l}$ dexamethasone (Paran and others, 1973) (Sigma Chemical, St. Louis, Mo.).

\section{CHEMICAL ENHANCERS OF VIRUS REPLICATION}

Induction of type $\mathrm{C}$ virus replication (Rowe and others, 1972) was attempted by adding 5-iododeoxyuridine (IDU; Calbiochem, La Jolla, Calif.) to one replicate set of cultures in each experiment (including controls) at $30 \mu \mathrm{g} / \mathrm{ml}$ medium, usually for the first 4 days of culture (Table II). IDU was added again later in three experiments (Table II), usually for 4 days after subculture. An untreated replicate set was always included.

Phytohaemagglutinin (PHA; $10 \mu \mathrm{g} / \mathrm{ml}$ medium; Bactophytohemagglutinin P, Difco Labs, Detroit, Mich.) was added to both IDU-treated and untreated replicate culture sets in experiment $1 \mathrm{~A}$ for the first 4 days. Replicate sets not treated with PHA were included.

\section{RADIOLABELLING OF CULTURES}

Labelling of type $C$ virus RNA was attempted by adding uridine $-5^{\prime}-{ }^{3} \mathrm{H}$ (aqueous, specific activity $>25 \mathrm{Ci} / \mathrm{mmol}$ per 1; New England Nuclear, Boston, Mass.) to the cultures at 10-20 $\mu \mathrm{Ci} / \mathrm{ml}$ medium (Robinson and others, 1965; Sarma and others, 1970; Phillips, 1975b). The first labelling was usually done starting on day 1-2 of the experiments, when cells were actively multiplying. After incubation for 2-4 days, the medium was harvested, clarified $\left(2000 \mathrm{~g}, 15 \mathrm{~min}, 4^{\circ} \mathrm{C}\right)$ and the supernatants frozen at $-70^{\circ} \mathrm{C}$ for later ultracentrifugation. Cultures were refed and sequential 2- to 4-day labelling and harvests done in many experiments (Table II), so that many cultures were labelled continuously for as long as 10 days. Significant radioactivity remained in the cultures so the next medium change 3-5 days later was also usually harvested and tested.

Experiments 1B, 5B, 7, 7T, and 8 were done in duplicate or quadruplicate initially, with complete set(s) of replicate cultures being unlabelled initially. The same harvests were made as in the labelled sets, and used for electron microscope and RNA-directed DNA polymerase assays for type $C$ viruses. These unlabelled replicate sets were later radiolabelled after 3-4 weeks and/or used for replicate subcultures, one set of which was then labelled immediately as described above for the initial cultures. The total number of times each experiment was radiolabelled is shown in Table II.

\section{ULTRACENTRIFUGATION}

In early experiments $2 \mathrm{ml}$ of the radiolabelled harvests were layered directly onto $3 \mathrm{ml} 20 \%$ sucrose cushions over $25 \mathrm{ml}$ linear $20-60 \%$ sucrose gradients. Sucrose solutions were made weight/volume in buffer $(0.01 \mathrm{~mol} / 1$ TRIS, $0.001 \mathrm{~mol} / 1$ EDTA, $0.05 \%$ 2-ME, $0.1 \mathrm{~mol} / 1$ $\mathrm{NaCl}, \mathrm{pH} \mathrm{7.4)}$. These gradients were ultracentrifuged in an SW 25.1 rotor at $22000 \mathrm{rpm}$ for 4.5 hours at $4^{\circ} \mathrm{C}$ (L2-50, Beckman Instruments, Palo Alto, Calif.). $1 \mathrm{ml}$ fractions were collected by bottom puncture and the density of every fourth fraction measured with a refractometer (Hitachi hand protein model) using sucrose solutions of known density as standards. Then $0.1 \mathrm{ml}$ of $7.5 \%$ fetal calf serum (in distilled water) was added as carrier protein and each fraction precipitated with $1 \mathrm{ml}$ of cold $20 \%$ trichloracetic acid. Washed precipitates were collected on $0.45 \mu \mathrm{m}$ filters (Millipore, Bedford, Mass.), put in $10 \mathrm{ml}$ Bray's solution and ${ }^{3} \mathrm{H}$ cpm measured in a Packard scintillation spectrometer (Robinson and others, 1965; Sarma and others, 1970; Phillips, 1975b).

In later experiments $2 \mathrm{ml}$ of the labelled harvests were precipitated with an equal volume of cold saturated ammonium sulphate, collected (SS-34 rotor, $15700 \mathrm{rpm}$, 5 min, $4^{\circ} \mathrm{C}$; RC-2B, Ivan Sorvall, Norwalk, Conn.) and redissolved in $0.5 \mathrm{ml}$ buffer. These were layered onto $1.5 \mathrm{ml} 20 \%$ sucrose cushions over $10 \mathrm{ml}$ linear $20-60 \%$ sucrose gradients and ultracentrifuged in an SW 41 rotor (Beckman) at $40000 \mathrm{rpm}$ for $90 \mathrm{~min}$ at $40^{\circ} \mathrm{C}$ (Sarma and others, 1970). $0.5 \mathrm{ml}$ fractions were collected and analysed as described above. Comparable results were obtained with either procedure.

For a positive control supernatant medium containing a murine type $\mathrm{C}$ virus from infected mouse cells radiolabelled with ${ }^{3} \mathrm{H}$-uridine $(4 \mu \mathrm{Ci} / \mathrm{ml}$ for 16 hours) was used. This was made in a different building; at no time have known type $\mathrm{C}$ viruses been grown in the laboratory where the SLE isolation experiments were conducted.

TYPE C VIRUS RNA-DIRECTED DNA POLYMERASE (RDDP) ASSAYS AND ELECTRON MICROSCOPY

Viral RDDP assays were done on pellets (type 50 rotor, $19000 \mathrm{rpm}, 90 \mathrm{~min}, 4^{\circ} \mathrm{C}$; Beckman) of supernatants from the unlabelled replicate sets of cultures (Expts. 1B, 5B, 7, 7T, and 8, Table II) using the method of Stephenson, Reynolds, and Aaronson (1972). Electron microscopy on a portion of these pellets was done by negative staining techniques described previously (Sarkar and Moore, 1974).

\section{Results}

The known murine type $\mathrm{C}$ virus positive control gave a sharp peak in the $1 \cdot 15-1 \cdot 17 \mathrm{~g} / \mathrm{ml}$ density region of the gradient (Figure $A$ ). The first gradient from SLE cells in the first experiment was similarly positive (Figure $B$ ), while the non-SLE controls were negative. No other gradients in this experiment were unequivocally positive (Table III). Positive gradients were defined as a single sharp peak at the $1 \cdot 14-1 \cdot 17 \mathrm{~g} / \mathrm{ml}$ density region which was composed of two or more fractions with at least one having more than $200 \mathrm{cpm}$ (Figure $D$ ). Equivocal $( \pm$ ) gradients (Table III) were defined as single peaks in this region not meeting the above criteria, and as multiple or broad peaks at this and other densities.

The conditions giving the first positive result were duplicated exactly in a repeat experiment several months later (Expt. 1B) at which time the experiment was also enlarged and done in four replicate sets, 
two labelled and two unlabelled. The exact duplication of Expt. 1A was negative but, under somewhat different conditions, there were two positive gradients (Table III). One was early (day 4), but its labelled replicate was negative. The other, though cultured under similar conditions (rabbit cells, IDU), was late (day 25). Repeat ultracentrifugation of this specimen was negative. Type $C$ virus RDDP and electron microscope analysis of the unlabelled replicate cultures of this experiment were completely negative, including two replicates of the early positive gradient and one of the later positive.

Experiments 2-5A, 6, and 8 were negative (Table III), as was 5B except for a control non-SLE cell culture (mink cells, IDU twice, second subculture). Unlabelled replicates in this experiment were all negative by RDDP assay and electron microscopy, as were those from Expt. 8. Expt. 7 provided some highly positive gradients, but these occurred both with SLE cultures (Figure $C$ ) and non-SLE controls (Figure $D$, Table III). Repeat gradients on the positive SLE and control harvests illustrated were negative. However, a second repeat on the control
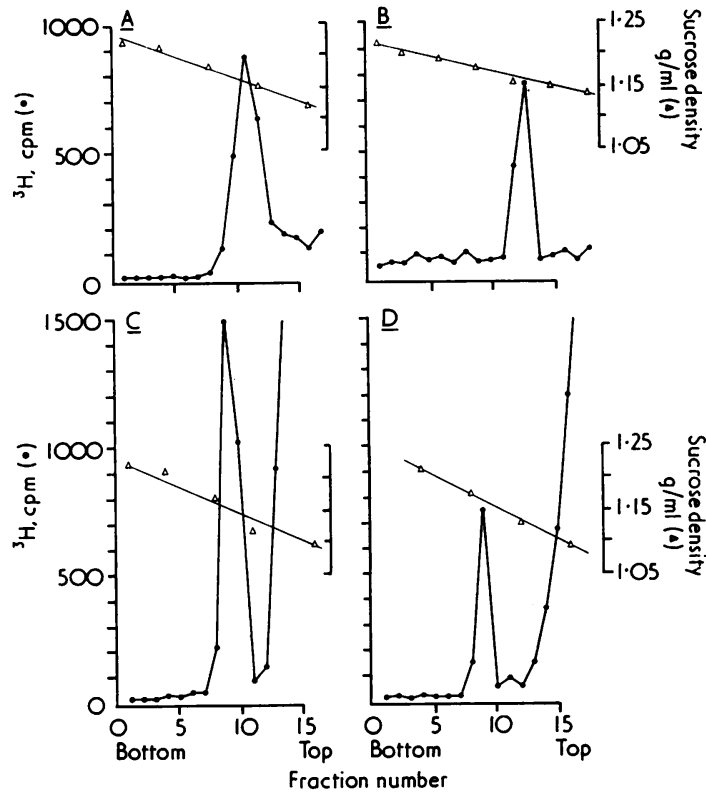

FIGURE $1 \cdot 14-1 \cdot 17 \mathrm{~g} / \mathrm{ml}$ peaks after isopycnic ultracentrifugation of ${ }^{3} \mathrm{H}$-uridine-labelled cell culture supernatants on sucrose gradients. A Positive control: gross murine leukaemia virus (2 $\mathrm{ml}, \mathrm{NH}_{4} \mathrm{SO}_{4}$ precipitate, $S W-41)$. B SLE peripheral blood leucocyte culture, first harvest, day 4 (2 ml, SW-25·1; Expt. 1A). C SLE placenta culture with iododeoxyuridine, first harvest, day $4(0.5 \mathrm{ml}$, SW-41; Expt. 7). D Control for SLE (Fig. C); mink cell culture with iododeoxyuridine, first harvest, day $4(0.5 \mathrm{ml}$, SW-41; Expt. 7)
Table III Presence of ${ }^{3} \mathrm{H}$-uridine-labelled peaks in sucrose gradients at the $1.16 \mathrm{~g} / \mathrm{ml}$ density region

\begin{tabular}{|c|c|c|c|c|c|c|}
\hline \multirow{3}{*}{$\begin{array}{l}\text { Experiment } \\
\text { no. }\end{array}$} & \multicolumn{6}{|c|}{ No. of gradients } \\
\hline & \multicolumn{3}{|c|}{$S L E$} & \multicolumn{3}{|c|}{ Control } \\
\hline & $+^{*}$ & \pm & 0 & + & \pm & 0 \\
\hline $\begin{array}{l}1 \mathrm{~A} \\
1 \mathrm{~B} \dagger \\
2-5 \mathrm{~A} \\
5 \mathrm{~B} \dagger \\
6 \\
7 \dagger \\
7 \mathrm{~T} \dagger+ \\
8 \dagger\end{array}$ & $\begin{array}{l}1 \\
2 \\
0 \\
0 \\
0 \\
4 \\
2 \\
0\end{array}$ & $\begin{array}{r}5 \\
3 \\
0 \\
5 \\
1 \\
10 \\
2 \\
0\end{array}$ & $\begin{array}{r}18 \\
43 \\
22 \\
22 \\
15 \\
23 \\
20 \\
8\end{array}$ & $\begin{array}{l}0 \\
0 \\
0 \\
1 \\
3 \\
3 \\
0 \\
0\end{array}$ & $\begin{array}{l}1 \\
2 \\
1 \\
5 \\
0 \\
2 \\
0 \\
1\end{array}$ & $\begin{array}{r}11 \\
18 \\
1 \\
13 \\
8 \\
81 \\
22 \\
4\end{array}$ \\
\hline Total & 9 & 26 & 171 & 4 & 12 & 98 \\
\hline
\end{tabular}

* See text for explanation.

† Type C virus RDDP assay and electron microscopy negative throughout on unlabelled replicate culture sets.

$\ddagger$ Transmission experiment from no. 7 .

was positive, although with a 12 -fold reduction in size of the peak. RDDP assay and electron microscopy on unlabelled replicates were again negative throughout, including those positive by the gradients.

Positive gradients usually occurred early in the experiments and were never found sequentially from the same culture. Equivocally positive gradients were more frequent (Table III) and usually occurred later. Most of these had either several sharp peaks (often with one at $1 \cdot 14-1 \cdot 17 \mathrm{~g} / \mathrm{ml}$ ) or a broad peak spanning most of the gradient $(1 \cdot 12-1 \cdot 20 \mathrm{~g} / \mathrm{ml})$. The latter in particular suggested cell damage was occurring with release of cellular components of varying density which contained labelled RNA. A typical sequence of gradients was from the labelled SLE and mink coculture in Expt. 7 where the first harvest (day 4) was negative, the second (day 8) positive with a moderate size $1 \cdot 15-1 \cdot 16 \mathrm{~g} / \mathrm{ml}$ peak (similar to Figure $D$ ), the third (day 11) equivocal with a large $1 \cdot 17-1 \cdot 19 \mathrm{~g} / \mathrm{ml}$ peak, and the fourth (day 15 ) equivocal with a broad $1 \cdot 14-1 \cdot 19 \mathrm{~g} / \mathrm{ml}$ peak. The parallel mink control culture gave similar results except that the equivocal day 11 peak was broad $(1 \cdot 12-1 \cdot 20 \mathrm{~g} / \mathrm{ml})$.

Aliquots of the third SLE and second control harvests were examined with the electron microscope and no virus particles found. By light microscopy these and the other labelled cultures contained larger cells which grew less well than the unlabelled replicate cultures. If labelled repeatedly, as in this experiment, they later showed progressive degeneration: the SLE mink coculture was nearly dead by day 18 and the mink control by day 15 , while the unlabelled replicates remained in good condition and were subcultured on day 41 . This was recognized as a general pattern after analysing the various conditions used in the experiments. There was a good 
correlation between damaged or dying cells by light microscopy and the appearance of broad peaks, while unequivocally positive gradients occurred earlier when cytotoxicity was less pronounced. The cell damage was due to the radiolabelling, as the otherwise identical unlabelled replicates did not show it. Altered cell morphology was visible as early as day 3-4 of labelling, and the number of radiolabellings in an experiment (Table II) generally correlated with the number of positive and equivocal gradients (Table III).

It was also noted that some cell types were more radiosensitive than others, e.g. in Expt. 7 mink cell cultures degenerated more than rabbit cultures, and produced more positive and equivocal gradients (10 vs 2). An attempt was made to quantitate cell damage in Expt. 7 using cellular release of glutamicoxaloacetic transaminase into the labelled culture medium. Levels of this enzyme were not a sensitive indicator of visible cytotoxicity and did not correlate with the gradient results.

In spite of the lack of corroborative evidence for a viral nature of the peaks, an attempt was made to transmit them to uninoculated cultures (Expt. 7T). A positive SLE harvest (Figure $C$ ), a negative harvest from a replicate SLE culture (but not IDUtreated), a negative non-SLE culture harvest (rabbit, IDU), all from day 4 of Expt. 7, and Hanks's solution were inoculated onto rabbit and mink cultures as described above in methods. Two positive gradients were found after the first labelling (Table III), one each with the previously positive and previously negative SLE inocula. The next two harvests from the latter were equivocally positive with 1 fraction peaks in the $1 \cdot 16-1 \cdot 17 \mathrm{~g} / \mathrm{ml}$ region. Three subcultures and, on unlabelled replicates, RDDP assay and electron microscopy were all negative.

\section{Discussion}

Previous attempts, including our own, at isolating viruses from SLE patients have been negative (Phillips, 1975a), but have not been specifically directed at type $\mathrm{C}$ viruses. This is the first such study reported; a variety of techniques previously successful in isolating type $\mathrm{C}$ viruses from lower species were used (Todaro, 1974). Prolonged cell culture or treatment with 5-iododeoxyuridine or PHA can induce virus replication (Rowe and others, 1972; Marsh, Miller, and Hanson, 1973; Panem and others, 1975). Maintenance of actively dividing cells by frequent subculture enhances virus replication, as can the addition of dexamethasone to the cultures (Sarma and others, 1970; Paran and others, 1973; Aaronson, Stephenson, and Greenberger, 1975; Panem and others, 1975).

DEAE-dextran treatment aids virus attachment (Toyoshima and Vogt, 1969). Cocultivation with permissive cells from heterologous species results in replication of xenotropic type $\mathbf{C}$ viruses (Benveniste and others, 1974b; Henderson and others, 1974), such as that isolated from a baboon placenta (Benveniste and others, 1974a). Type $C$ virus-like particles have been found in human placentas and were present in the placenta from Case 7, although not in the tissues from Cases 5 and 8 (Imamura, Phillips, and Mellors, 1976). Detection of ${ }^{3} \mathrm{H}-$ uridine-labelled type $C$ viruses at $1 \cdot 15-1 \cdot 17 \mathrm{~g} / \mathrm{ml}$ density by isopycnic sedimentation in sucrose gradients is a well-established method of reasonable sensitivity (Robinson and others, 1965; Sarma and others, 1970; Todaro, 1974). All these methods were applied in the present study without success.

Although the nature of the $1 \cdot 14-1 \cdot 17 \mathrm{~g} / \mathrm{ml}$ peaks found here was not determined exactly, the evidence they were not type $C$ viruses is substantial. Repeat ultracentrifugation was negative with one exception: replicate cultures and repeat experiments were negative; positive cultures were not so sequentially or after subculture; transmissibility was not established and control cultures were sporadically positive. In addition, type $C$ virus particles were not found by electron microscopy either in positive harvests or in identical replicate culture harvests. Finally, assays for type C virus RDDP on replicate cultures were repeatedly negative. This evidence als argues against the peaks being due to other RNA viruses or mycoplasma (Todaro, Aaronson, and Rands, 1971), even though these do not normally sediment in the $1.16 \mathrm{~g} / \mathrm{ml}$ region.

That these peaks were due to release from damaged cells of organelles containing ${ }^{3} \mathrm{H}$-labelled cellular RNA was suggested by their disappearance (in one instance only, a marked reduction in size) on repeat ultracentrifugation. This involved a second freezethawing of the sample which would rupture fragile cellular organelles. In addition, the more frequent appearance of broad or multiple peaks correlated with light microscopically visible cellular damage. These equivocal peaks appeared later than the positive ones, when the cultures were older and had been radiolabelled for longer periods. These cultures subsequently degenerated, while the unlabelled ones survived and were used for subcultures.

Others have found broadly sedimenting peaks of ${ }^{3} \mathrm{H}$-uridine-labelled material after relatively long periods (4 days) of radiolabelling (Benz and Moses, 1974). Using electron microscopy, these were interpreted as possibly due to a virus present in the fetal calf serum (Benz and Moses, 1974). Subsequently, evidence was presented that such 'viruslike' particles were in fact cellular material, in part derived from degenerating mitochondria (Dalton, 1975). These microvesicles would likely contain cellular RNA, and although not specifically looked for, they were occasionally noted in this study. Thus 
it is probable the positive results obtained here were due to release of cellular RNA from cells damaged by prolonged radiolabelling (Henry, 1967). Such artefactually positive results are a potential problem in other studies using this method for detecting RNA viruses.

Although this study is a negative attempt at isolating type $C$ virus from SLE patients, a variety of evidence suggests such viruses may be involved in the pathogenesis of SLE (Phillips, 1975a). If this is correct then failure at isolation may be due to lack of a complete virus genome in the cells studied with a consequent inability of the virus to replicate. However, a more likely explanation is that the complete genome is present (Todaro, 1974), but the test conditions were inappropriate. The appropriate conditions for isolating human type $C$ viruses of the endogenous class like that involved in New Zealand mouse disease (Levy and others, 1975) have not yet been reported. Therefore we are continuing type $\mathrm{C}$ virus isolation attempts using the less laborious assay for viral RDDP in conjunction with sensitive viral amplification methods.

We thank Dr. Theodore Pincus for providing radiolabelled murine type $C$ virus and the RDDP assays, Dr. Jose Granda for glutamic-oxaloacetic transaminase assays, our physician colleagues for help in obtaining specimens, Dr. Charles Christian for advice and support, and Mrs. Hjordis Kerezman for secretarial assistance.

Supported in part by grants from the United States Public Health Service National Institutes of Health (AM 17028 and 14627, CA 08748) and the John Lindsley Fund.

\section{References}

Aaronson, S. A., Stephenson, J. R., And Greenberger, J. S. (1975) J. Virol., 13, 1404 (Cellular replication and the persistence of inducible RNA type $C$ viruses)

Benveniste, R. E., Lieber, M. M., Livingston, D. M., Sherr, C. J., Todaro, G. J., and Kalter, S. S. (1974a) Nature, 248, 17 (Infectious type $C$ virus isolated from a baboon placenta)

,-- and Todaro, G. J. (1974b) Proc. Nat. Acad. Sci. (Wash.), 71, 602 (A distinct class of inducible marine type $C$ viruses which replicate in the rabbit SIRC cell line)

BenZ, E. W., JR., AND Moses, H. L. (1974) J. nat. Canc. Inst., 52, 1931 (Small viruslike particles detected in bovine sera by electronmicroscopy)

Christian, C. L., AND PHillips, P. E. (1973) Amer. J. Med., 54, 611 (Viruses and autoimmunity)

Cohen, A. S., Reynolds, W. E., Franklin, E. C., Kulka, J. P., Ropes, M. W., Shulman, L. E., and Wallace, S. L. (1971) Bull. rheum. Dis., 21, 643 (Preliminary criteria for the classification of SLE)

Dalton, A. J. (1975) J. nat. Canc. Inst., 54, 1137 (Microvesicles and vesicles of multivesicular bodies versus 'viruslike' particles)

Henderson, Z. C., Lieber, M. M., and Todaro, G. J. (1974) Virology, 60, 282 (Mink cell line Mv 1 Lu (CCL 64). Focus formation and the generation of 'non producer' transformed cell lines with murine and feline sarcoma viruses)

HeNRY, C. (1967) 'Labelling of viruses with isotopes' in 'Methods in Virology', eds. K. Maramarosch and H. Koprowski, Vol. II, Chapter 15. Academic Press, New York

Imamura, M., Phillips, P. E., and Mellors, R. C. (1976) Amer. J. Path. (In press) (The occurrence and frequency of type C viruslike particles in placentas from SLE patients and normal subjects)

KruSE, P. F., JR., AND Patterson, M. K., JR. (1973) (Editors) 'Tissue Culture. Methods and Applications'. Academic Press, New York

Levy, J. A., Kazan, P., Varnier, O., and Kleiman, H. (1975) J. Virol., 16, 844 (Murine xenotropic type C viruses. I. Distribution and further characterization of the virus in NZB mice)

Lewis, R. M., TANNenberg, W., Smith, C., AND Schwartz, R. S. (1974) Nature, 252, 78 (C-type viruses in SLE)

Marsh, R. F., Miller, J. M., and Hanson, R. P. (1973) Infect. Immunity, 7, 352 (Transmissible mink encephalopathy: studies on the peripheral lymphocyte)

Panem, S., Prochownik, E. V., Reale, F. R., AND KIRSTen, W. H. (1975) Science, 189, 297 (Isolation of type C virions from a normal human fibroblast strain)

Paran, M., Gallo, R. C., Richardson, L. S., AND Wu, A. M. (1973) Proc. Nat. Acad. Sci. (Wash.), 70, 2391 (Adrenal corticosteroids enhance production of type-C virus induced by IDU from cultured mouse fibroblasts)

PhILlIPS, P. E. (1971) J. exp. Med., 134 (2), 313s (Virologic studies in rheumatoid arthritis)

- (1975a) Ann. intern. Med., 83, 709 (The virus hypothesis in SLE)

- (1975b) 'Virologic studies in rheumatoid arthritis' in 'Immunological Aspects of Rheumatoid Arthritis' ('Rheumatology', Vol. 6), p. 353. Karger, Basel

Robinson, W. S., Pitkanen, A., And Rubin, H. (1965) Proc. Nat. Acad. Sci. (Wash.), 54, 137 (The nucleic acid of the Bryan strain of Rous sarcoma virus: purification of the virus and isolation of the nucleic acid)

Rowe, W. P., Lowy, D. R., Teich, N., AND Hartley, J. W. (1972) Ibid., 69, 1033 (Some implications of the activation of murine leukemia virus by halogenated pyrimidines)

SARKAR, N. H., AND MOORE, D. H. (1974) Virology, 61, 38 (Surface structure of mouse mammary tumor virus) 
Sarma, P. W., Huebner, A. S., Baskar, J. F., Vernon, L., Gilden, R. V., and Toni, R. (1970) Ibid., 41, 377 Feline leukemia virus detection in vitro)

Stephenson, J. R., Reynolds, R. K., AND Aaronson, S. A. (1972) Ibid., 48, 749 (Isolation of temperature sensitive mutants of murine leukemia virus)

STRAND, M., AND August, J. T. (1974) J. Virol., 14, 1584 (Type C RNA virus gene expression in human tissue)

TODARO, G. J. (1974) 'Biology of RNA- and DNA-containing oncogenic viruses' in 'Slow Virus Diseases', eds. W. Zeman and E. H. Lennette, p. 116. Williams and Wilkins, Baltimore

- Aaronson, S. A., AND Rands, E. (1971) Exp. Cell Res., 65, 256 (Rapid detection of mycoplasma-infected cell lines)

Toyoshima, K., AND VoGt, P. K. (1969) Virology, 38, 414 (Enhancement and inhibition of avian sarcoma viruses by polycations and polyanions)

Yoshiki, T., Mellors, R. C., Strand, M., ANd August, J. T. (1974) J. exp. Med., 140, 1011 (The viral envelope glycoprotein of murine leukemia virus and the pathogenesis of immune complex glomerulonephritis of New Zealand mice)

ZIFF, M. (1971) Ann. intern. Med., 75, 951 (Viruses and the connective tissue diseases) 